\title{
Bibliometric and Collaborative Network Analysis on Active Methodologies in Education
}

\author{
Adrián Segura-Robles $\odot$, María Elena Parra-González $₫$ and Miguel Ángel Gallardo-Vigil $\odot$ \\ Departamento de Métodos de Investigación y Diagnóstico en Educación, Universidad de Granada, Spain
}

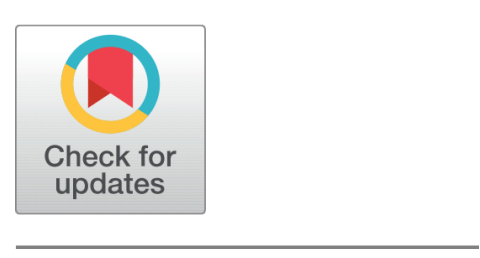

Received 2020-04-03

Revised 2020-04-06

Accepted 2020-05-13

Published 2020-07-15

\section{Corresponding Author}

Adrián Segura-Robles,

adrianseg@ugr.es

Facultad de Educación, Economía y Tecnología de

Ceuta, C/ Cortadura del Valle

S.N. C.P. 51001, (Ceuta) Ceuta, Spain

DOI https://doi.org/10.7821/

naer.2020.7.575

Pages: 259-274

Distributed under

Creative Commons CC BY 4.0

Copyright: (C) The Author(s)

\section{ABSTRACT}

Teachers have gradually been making more use of active methodologies at all educational levels, and some even carry out research in this area. The objective of this research was to develop a bibliometric study in order to gain an in-depth view of the scientific literature on active methodologies in education. An analysis of the classic descriptions of bibliometrics, co-authorship indexes and collaboration networks was carried out, using documents indexed by the Web of Science on active methodologies in education between 2009 and 2019. The final data corpus is composed of 513 documents. The results show that publications on this type of research are booming, demonstrating a growing interest in these kinds of studies in the short and medium term. English is the predominant language in these studies, as occurs in the general scientific literature. The results indicate a limited range of topics being studied currently and likely growth in coming years. Therefore, this category of research can be considered as a relevant field of study for the scientific community in the short and medium term.

\section{INTRODUCTION}

Teachers must be constantly in search of the most suitable teaching methodologies for their students (Gómez-López, 2002). It is necessary to adapt the teaching methodology to the student's level, their interests, needs, characteristics, evaluation ... and even to learn or acquire skills necessary with the student body (Fernandez-March, 2006). Currently, changes are needed in the methods of teaching since, thanks to technology, there have also been changes in the way we relate to others. Relationships between people and with the environment are now carried out in a different way, as technology has allowed this to be so. Thus, in recent years, the need for methodological renewal has been emphasized (Fernandez-March, 2006; Parra-González, Belmonte, Segura-Robles, \& Cabrera, 2020).

One of the main cores of debate in education is on how teachers teach and how students learn. This is why there is a need to search for and incorporate new teaching methodologies

\section{OPEN ACCESS}


which provide necessary training in critical and thoughtful approaches (Morales \& Pereida, 2017). Recently, there has been a lot of research on learning and learners' ways of thinking (Arenas-Loera, 2017).

It is in this context that the well-known active methodologies have emerged. As their name indicates, they are based on making students work actively during their learning (Bernal-González, Martínez-Dueñas, \& S, 2017; Masero-Moreno, 2016). The engagement of students in their learning process is very important (Hidalgo \& Perines, 2018; Méndez-García \& Trillo-Alonso, 2010) but the idea of student engagement does not only refer to participation in something that is being proposed, but also to the fact that this proposal should be something useful for the students, since students learn when a context is created in which they involve themselves in a meaningful way, from a deeper perspective (Biggs, 2015). One of the most essential features of this type of method is the search for an active attitude in the students, to transform them into active agents of their own education (Burganova, Abdullina, \& Tuyakova, 2018; Coll, 1997; Marchesi, Coll, \& Palacios, 2018).

This kind of methodology also arises as a response to the need for students to get involved and work actively since, according to Brewer et al. (2013), students lack involvement in their educational activities. All this is based on the fact that students have to be responsible for their learning (Contreras-Gastelum \& Lozano-Rodriguez, 2012).

The use of active methodologies can be applied to any area and content. This has been demonstrated by distinct experiences and researches in different thematic areas (NielsenRodriguez, Romance-Garcia, \& Minguet, 2020; Paños-Castro, 2017; Parra-González, Belmonte, et al., 2020; Parra-González, Segura-Robles, \& Gómez-Barajas, 2020; Romero, Pérez, \& Pérez, 2020; Silva-Quiroz \& Maturana-Castillo, 2017; Xi \& Hamari, 2020). It is considered one of the most effective tools to increase motivation and commitment of students at any educational stage (Bai, Hew, \& Huang, 2020; Cechetti et al., 2019).

The situation of active methodologies in education has evolved over time. Initially, it was used only by the most innovative teachers, and was seen as rather a modern thing. Some even viewed it in a negative way, as an experiment. However, given the benefits that have been seen in terms of its impact on education throughout experiences at various educational levels, as well as the results of different investigations on active methodologies, its use has been spreading and expanding, to the point that it is now seen as normal and frequent (Bernal-González et al., 2017; Fernandez-March, 2006; Parra-González \& SeguraRobles, 2019a). This is now true to such an extent that some authors are already beginning to establish the basis for the good use of certain active methodologies, such as the importance of taking into account certain elements, the creation of a good classroom atmosphere or, for example, the use of shared evaluation (Pérez-López \& García, 2017).

In this panorama of methodological renewal, becoming users of technology will facilitate the way in which knowledge is offered, since the globalized world in which we live is dominated by technologies, and these are also constantly changing (Arthur, 2016; Davies \& Chong, 2016). 
Bibliometrics is described as "the study of the quantitative aspects of production, distribution and use of published information" (Moed \& Glänzel, 2005, p. 343). Although the evolution of bibliometric studies has demonstrated its effectiveness as a tool for in-depth knowledge of a specific subject within the scientific field, it generally has an important limitation. This limitation, considered critical, arises from the usual rigidity of the analysis (by individual, by institutions, etc.), often leaving aside the study of social relationships between them (Reyes-Gonzalez, Gonzalez-Brambila, \& Veloso, 2016). In order to make up for this deficiency, in addition to the classical improved parameter studies (specific type analysis), different analysis of social collaboration structures can be carried out.

\section{METHODS}

The main methodology used for this study was a bibliometric analysis of the current state of research on active methodologies. The time frame was 2009-2019. This decision was justified by the fact that the number of publications that could be found in previous years is minimal and this could have distorted our results. Articles published in 2020 were also omitted, since it is the current year and all the documents have not been indexed yet. Considering 2020 releases so far, including them could distort the interpretation of the data.

The data corpus comprised both publications in scientific journals and conference communications published in WoS (Web of Science), which is one of the most internationally recognized databases (Jiménez-Noblejas \& Rodríguez, 2014).

The research questions were extracted from other studies with a similar methodology, typical in this type of study (Arguimbau-Vivó, Fuentes-Pujol, \& Gallifa-Calatayud, 2000; Flores et al., 2018; Parra-González, Belmonte, et al., 2020; Parra-González \& Segura-Robles, 2019b; Soto, Navas-Parejo, \& Guerrero, 2019):

- RQ1. How can the diachronic growth of the analyzed research be described?

- RQ2. Which publishers (congress or magazine) are the largest producers?

- RQ3. What is the author-publication relationship and who are the most productive authors?

- RQ4. Which are the most cited documents?

- RQ5. What are the central themes of the publications?

- RQ6. Which documents are considered classic among publications on the subject?

- RQ7. How do different countries collaborate in the production of research papers on the study of the subject?

- RQ8. Which institutions have the highest co-authorship numbers?

- RQ9. Which is the language with greatest influence in the specific scientific field?

- RQ10. Which is the research profile with the most projection?

\subsection{Inclusion Criteria}

In order to decide which documents were to be used for the analysis, we followed the following inclusion criteria. These criteria prevent inclusion of data that may distort the results 
of the analysis (Todeschini \& Baccini, 2016). The search conditions were established as follows.

- TOPIC: (( «active methodolog **) AND education $\left.{ }^{\star}\right)$

- Time period: 2009-2019.

- Databases: WOS, BCI, BIOSIS, CCC, DIIDW, KJD, MEDLINE, RSCI, SCIELO,

- Search language = All

- Documents published in magazines or conferences.

- Research domains SOCIAL SCIENCES, SCIENCE TECHNOLOGY, ARTS HUMANITIES.

Any document that did not meet these criteria or did not fit our study methodology for any reason was discarded and, thus, not included in the final corpus of documents.

\subsection{Procedure}

The work and analysis unit comprised a total of 587 publications of various kinds. Following the PRISMA protocol or Preferred Reporting Items for Systematic reviews and Metaanalysis (Moher, Liberati, Tetzlaff, \& Altman, 2009; Moher et al., 2015) the data was filtered in 4 stages: Identification, analysis of different international thesauri as to establish the equation and most efficient key terms for our research objective (Dios, Muñoz, AlonsoArroyo, \& Benavent, 2013), obtaining a total of 587 documents, visualization, where the inclusion criteria was applied and Eligibility, the last filter where those documents that would form the final corpus of analysis were selected. The final step was Inclusion (Figure 1).

In order to control for possible errors in selection and extraction of documents, the data was procured by two researchers in two separate searches. A reliability of 1.00 was obtained, both researchers registered the same number of articles.

Once the data was obtained, the analyses were carried out with different tools. For calculation of bibliographic characteristics and calculations of the different laws of bibliometrics, we used Bibibliometrix loaded on the RStudio integrated development platform. This tool allowed us to develop descriptive analyses and generate different collaboration networks on different variables (authors, keywords, etc.). For the elaboration of the term map and the visualization of the strength of its links, we used the VOSviewer tool, ideal for construction and visualization of related networks (Jiménez-Noblejas \& Rodríguez, 2014).

Co-authorship and co-citation networks are the most used analysis for social collaboration (Rousseau, Egghe, \& Guns, 2018). This aims to discover, for example, groups of frequent authors with great influence on literature or even to discover groups of hidden authors, as well as relevant institutions in relation to a specific scientific corpus.

Once the information was loaded and filtered, the following variables were considered for subsequent bibliometric analysis: a) annual trend of documents published from 2009 to 2019; b) Bradford zonal distribution; c) author-document correlations; d) productivity of the main authors; e) analysis of keyword networks; f) analysis of co-authorship networks; 


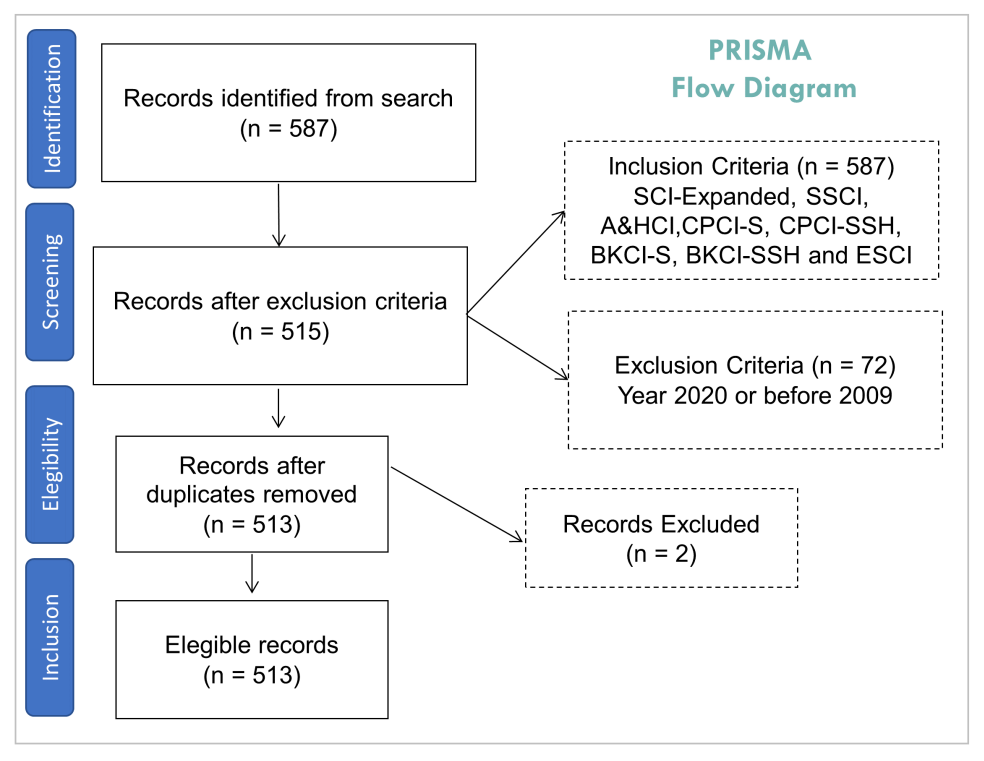

Figure 1 PRISMA research system for literature analysis (Moher et al., 2009)

g) analysis of co-citations. A preliminary reading of the abstract was carried out and, if necessary, in some cases a more exhaustive reading of the article was undertaken, to verify that it met the stated inclusion criteria.

\section{RESULTS}

Price and De (1986) believes scientific literature does not develop at a similar rate to other phenomena (social, biological, etc.), but rather at a much higher rate, reaching a doubled volume of literature on a specific subject, in a period of between 10-15 years. Figure 2 shows the rapid growth of literature around active methodologies in recent years. From 2009, where the number of publications reached 11 documents, until 2012, only three years later, the number of investigations increased to 38 , representing an increase of $245.45 \%$. Although in 2013 the number of publications seemed to decline (29), in the following years the trend changed again, being positive until 2017 and 2018, reaching a total of 94 publications each year. This increase, compared to 2011, represented a growth of $754.55 \%$. Although there were some decreases in specific years, the trend of this type of study continued to be that of positive growth.

The next proposed step was to identify the journals with the greatest accumulation of knowledge on the subject. According to Bradford (1985), science around a subject is accumulated in a particular number of specific publications, which he calls core journals. This procedure is, for example, the one used by WOS itself to organize its quartiles. As Fig- 


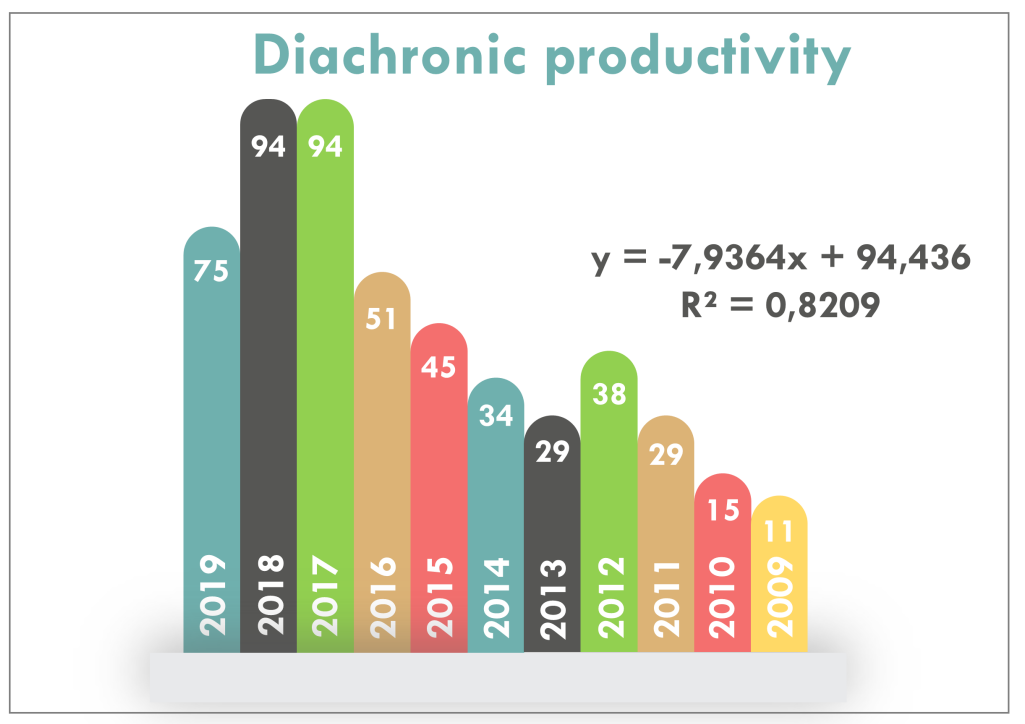

Figure 2 Diachronic productivity on active methodologies

ure 3shows, there are a total of 513 publications that accumulated the bulk of the work on active methodologies. Regarding the core, 18 sources accumulated up to 170 publications, followed by zone 1, made up of 60 sources that accumulated 175 documents. Finally, the last zone consists of 162 sources with a total of 168 documents.

Table 1 shows the names of publications in this core area and type of publication. Although the largest producers in the core area are divided into 5 conferences and 5 magazines, the former accumulated a greater number of documents. Thus, it was the International Technology, Education and Development Conference (INTED), with 60 published documents, that accumulated the greatest number of publications. It is not until fifth position that the REDU University Teaching Magazine appears, accumulating in this case 12 documents. It is necessary to be cautious when interpreting these data since publications made through conferences and their different calls (mostly annual), accumulated with a large flow of participants.

The next step was to identify the most productive authors on the subject. This analysis has a double purpose; on the one hand, to identify compliance with Lotka's law (1926) and, on the other, to identify documents with the highest number of citations. For Lotka (1926), most science gathers around a small group of specialized authors.

Following this premise, Figure 4(a) shows that Lotka's law is fulfilled for the set of documents analyzed. It can be seen that only 3 authors have published 6 documents related to active methodologies, while 1351 of them are directly or indirectly related to only one published document on the subject. Furthermore, results indicate a multiple correlation index 


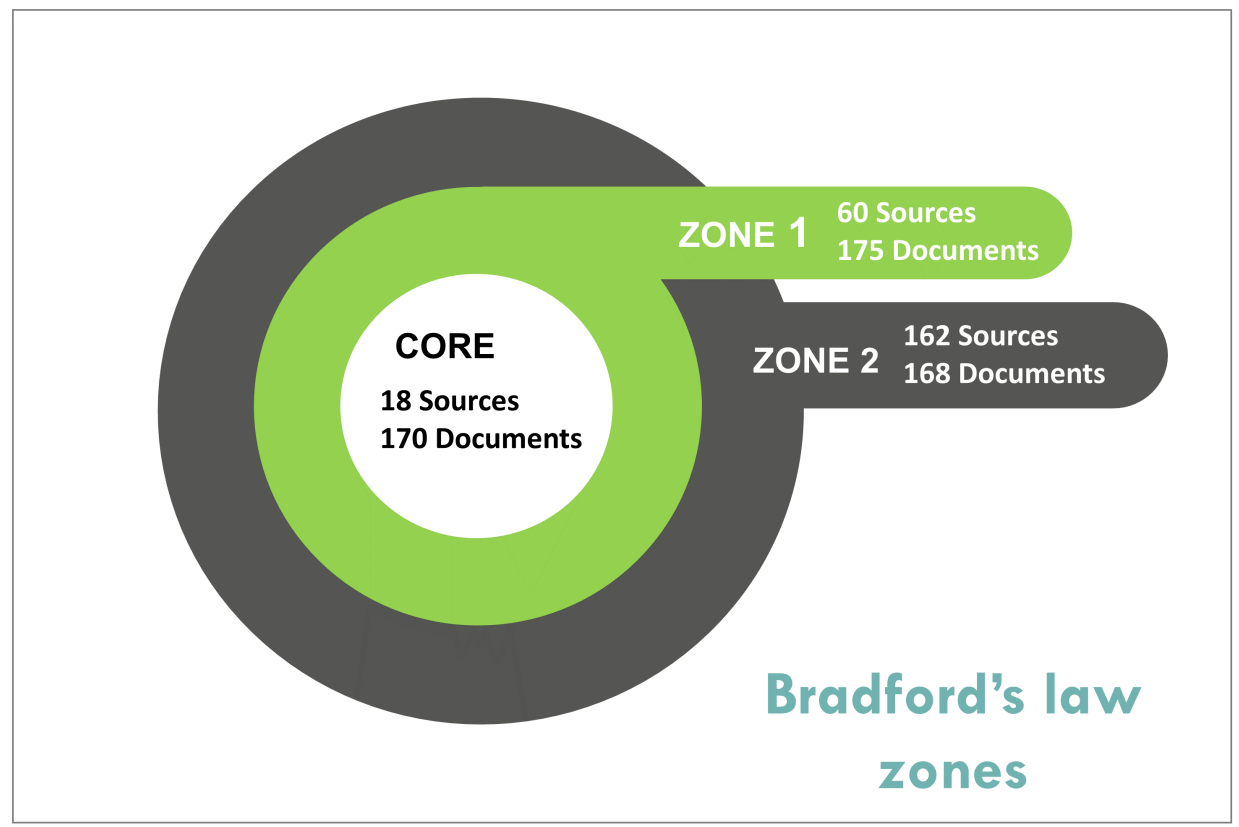

Figure 3 Bradford's law zones

Table 1 Productivity depending on the type of document analyzed

\begin{tabular}{|c|c|c|}
\hline Document & Sources & Type \\
\hline International technology, education and development conference (INTED) & 60 & Conference \\
\hline International conference on education and new learning technologies (EDULEARN) & 29 & Conference \\
\hline International conference of education, research and innovation (ICERI) & 22 & Conference \\
\hline Workshop on educational innovation in architecture (JIDA) & 12 & Conference \\
\hline REDU-revista de docencia universitaria & 12 & Journal \\
\hline Congreso nacional de innovación educativa y docencia en red (INRED) & 10 & Conference \\
\hline Interface-comunicação saude educação & 10 & Journal \\
\hline International journal of engineering education & 10 & Journal \\
\hline Revista brasileira de Enfermagem & 7 & Journal \\
\hline Revista ibero-americana de Estudos em Educação & 7 & Journal \\
\hline Advances in physiology education & 5 & Journal \\
\hline @TIC-Revista d'innovació educativa & 5 & Journal \\
\hline Cadernos educação tecnologia e sociedade & 5 & Journal \\
\hline IEEE Revista Iberoamericana de Tecnologias del Aprendizaje & 4 & Journal \\
\hline Administracao-ensino e pesquisa (RAEP) & 4 & Journal \\
\hline Contextos educativos-Revista de educacion & 4 & Journal \\
\hline Revista Edapeci-educação a distancia e praticas educativas comunicacionais e interculturais & 4 & Journal \\
\hline
\end{tabular}


of $\mathrm{R}^{2}=.93$, showing a very good fit.
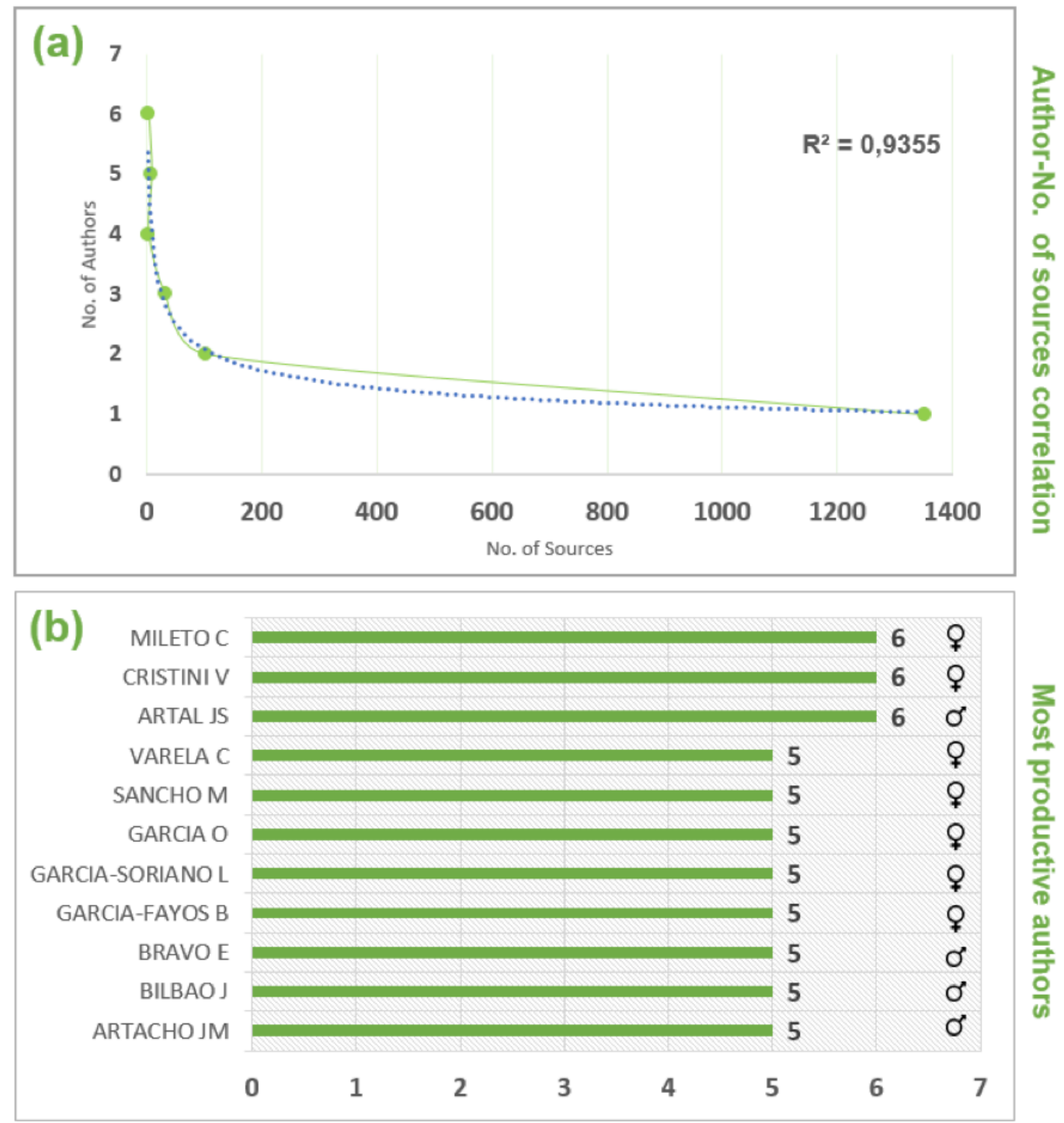

Figure 4 Correlation between number of authors and the number of documents (a) and authors with the highest accumulated production

In a similar way, in our analysis based on language for publishing or sharing of these documents, we found four main languages. The first of them is English, with $49.54 \%$ of the results, followed by Spanish with $30.34 \%$ and Portuguese with $23.58 \%$. To interpret these results, it is important to know that WOS itself can publish the same document in two languages, English being the common language. In contrast, the countries with the highest production are Spain, with $54.84 \%$, Brazil with $38.71 \%$ and Chile with $4.57 \%$ of accumulated documents, none of them in English.

To provide a deeper insight into the diachronic progression presented above, (b) shows which are the key authors or more productive authors regarding studies related to active 
methodologies. At the top of the list we found three authors with the same number of accumulated publications (6), Artal, JS, Crustubu, V. and Mileto, C. They are followed by 8 authors with 5 publications on the use of active methodologies in education each. In this same figure, the gender of the authors was analyzed. Women were represented by 7 authors (63.64\%) and men by 4 authors (36.36\%) showing, therefore, a majority of female representation for the subject matter.

Continuing with the analysis, the 5 documents with greatest impact in the time lapse are presented in Table 2. Except for the document published in «International Conference On Education And New Learning Technologies», the rest of the documents were published in indexed journals. Receiving a total of 63 citations, the document published by SáezLópez JM; Sevillano-García Ml; Vázquez-Cano E was the most-cited. Furthermore, it was observed that the most cited document was located in the journal with greatest impact, calculated by the WOS itself, with 5,627 (Impact for the last 5 years). It was also verified that among the 5 publications with greatest impact we did not find any of the most productive authors analyzed in the previous paragraph.

Table 2 Sources with the greatest impact according to the number of citations received.

\begin{tabular}{|c|c|c|c|}
\hline Authors & Cites & Source & Impact $^{*}$ \\
\hline $\begin{array}{l}\text { Sáez-López, J. M., Sevillano-García, M., \& Vázquez- } \\
\text { Cano, E. "Visual programming languages integrated } \\
\text { across the curriculum in elementary school: A two } \\
\text { year case study using Scratch in five schools" }\end{array}$ & 63 & Computers \& Education & 5.627 \\
\hline $\begin{array}{l}\text { Paranhos, V. D., \& Mendes, M. M. R. "Competency- } \\
\text { based curriculum and active methodology: percep- } \\
\text { tions of nursing students" }\end{array}$ & 19 & $\begin{array}{l}\text { Revista latino-americana de } \\
\text { Enfermagem }\end{array}$ & 1.371 \\
\hline $\begin{array}{l}\text { Prado, H., Falbo, G. H., Falbo, A. R., Figueiroa, J. N. } \\
\text { "Active learning on the ward: outcomes from a com- } \\
\text { parative trial with traditional method" }\end{array}$ & 16 & Medical Education & 4.619 \\
\hline $\begin{array}{l}\text { Ponsa, P., Amante, B., Román, J., Oliver, S., Diaz, M., } \\
\text { \& Vives, J. "Higher education challenges: introduc- } \\
\text { tion of active methodologies in engineering curric- } \\
\text { ula" }\end{array}$ & 15 & $\begin{array}{l}\text { International Journal of Engineer- } \\
\text { ing Education }\end{array}$ & 0.611 \\
\hline $\begin{array}{l}\text { Arbelaitz, O., Martin, J. I., \& Muguerza, J. "Analysis of } \\
\text { introducing active learning methodologies in a basic } \\
\text { computer architecture course" }\end{array}$ & 15 & $\begin{array}{l}\text { International Conference on Edu- } \\
\text { cation And New Learning Tech- } \\
\text { nologies }\end{array}$ & - \\
\hline
\end{tabular}

${ }^{\star}$ JCR 2018 impact factors

Based on the bibliographic data gathered from the WoS central collection, a visualization map of the different social networks was created with VOSviewer. The size of the circles represents the number of documents, so the larger the circle, the more documents it contains.

Figure 5(a) shows the graph of relationships between the different descriptors and keywords most used by the authors of the analyzed documents (513). In the figure, 4 different clusters are distinguished, the first of them composed of 31 key items (red), the second of them with 16 (green), the third with 2 (blue) and the fourth with only 1 (yellow). The size represented by each of the words is directly related to the number of times it appears, and 
the number of times it is related to the other descriptors (binding force).

The simpler but stronger cluster (2 items) (active: 11657 and methodologies: 9282) is blue, which is a logical result as the type of study analyzed here is in one way or another related to active methodologies. It is, compared to the rest of the clusters, the one that can offer the most information about the research scene on active methodologies. Thus, although a great variety of themes and connections between the different clusters is shown, the yellow cluster indicates a relevant concept related to many of the investigations: higher education.

On the other hand, following the results of the green and red cluster, it is noted that these studies focus around the implementation, development or evaluation of active methodologies, and how they improve or influence learning, also highlighting studies developed in the field of engineering. Likewise, the most studied or analyzed active methodologies in the documents extracted from the WOS are flipped classroom and project-based learning.

Likewise, the social structure was analyzed to study how authors and institutions are related within the same scientific area. Figure 5(b) shows results for co-citation analysis. Co-citation is understood as the "co-occurrence relationship that happens when two items in the existing literature are cited together by a third party" (Miguel et al., 2007 , p. 141).

In this sense, and based on co-citation, it is shown that the most relevant authors that have published on active methodologies in education have at least fifteen citations, according to WOS data. Thus, Paul Freire and David W. Johnson stand out as reference authors. Despite also having much more recent references, most articles also take classical education theorists into account in their research.

In the mapping process of Figure 5(c), representing the analysis of co-authorships by country, the lowest threshold of documents per country was established at 3. Of 51 possible countries, 12 were selected for viewing. Five main cores are distinguished, and separated by color. In this context, for example, Spain ( $\mathrm{n}=337$, purple node) and Brazil ( $\mathrm{n}=127$, green node) stand out as the countries with more collaboration networks and deeper links with the rest of the countries in terms of research on active methodologies at the educational level. The United States (turquoise node) is the one that has the lowest variety of links with the rest of the countries.

Finally, the analysis of co-authorships with respect to the institution shows 4 nodes. All of them are with Spanish universities as major collaborators. These clusters seem to follow a collaborative relationship mediated by the geographical proximity of the institutions themselves. The University of Zaragoza stands out in this area, with a total of 6 links.

Finally, in order to answer the last research question posed, a synthesis or summary of the main findings was carried out. Currently, studies on active methodologies at an investigator level are the order of the day, and this growth has followed a positive exponential curve. As a guideline, and seeking the widest international projection (number of citations) for possible future researchers, the journals Computers \& Education and Revista latino-americana de Enfermagem or conference papers from International Conference on Education and New Learning Technologies are recommended. However, these profiles are very specific and may not be suitable for all areas. Other options with huge possibilities within the field are confer- 

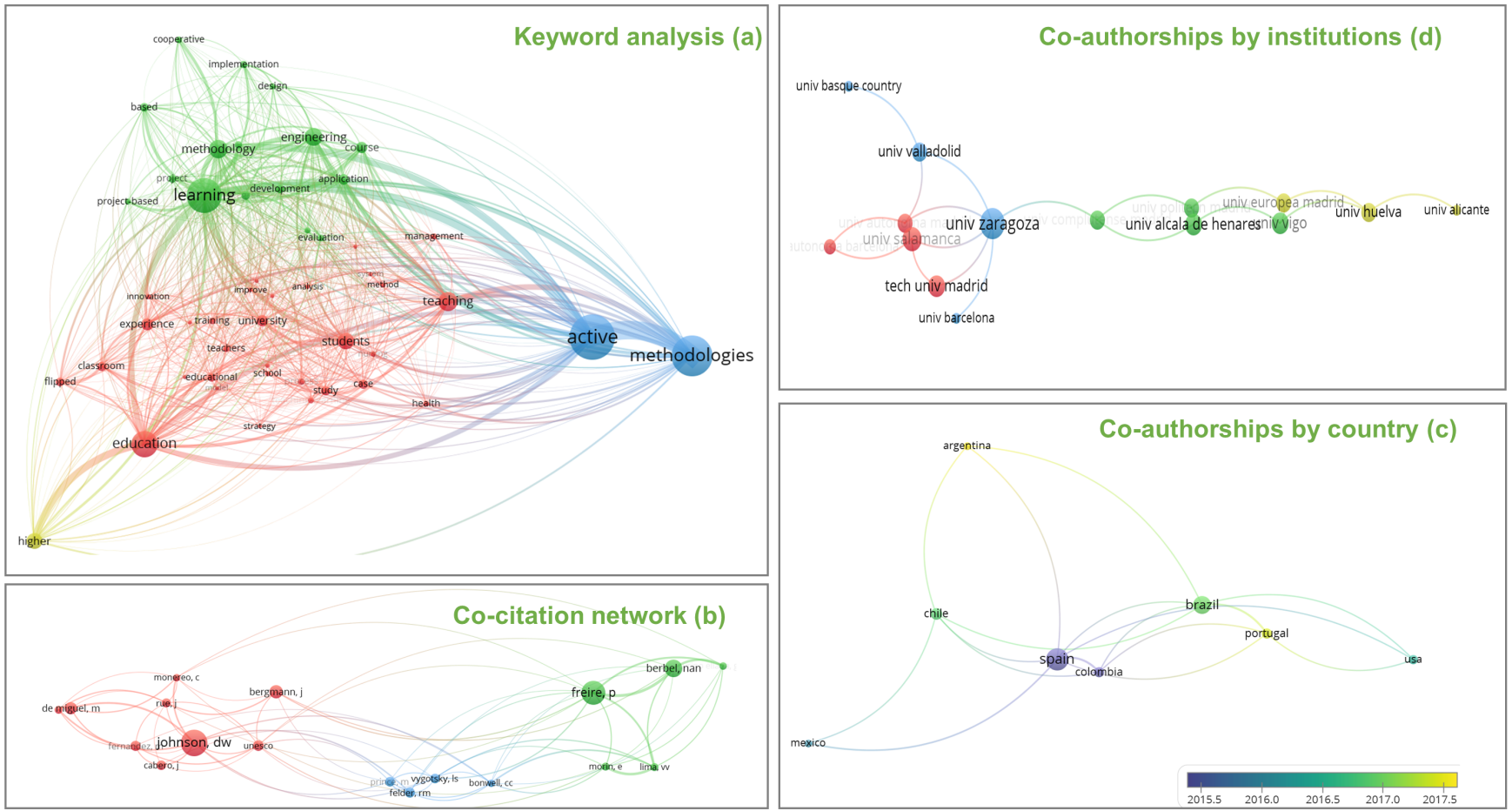

Figure 5 (a) Keywords analysis. (b) Co-citation network. (c) Co-authorships by country. (d) Co-authorships by institutions

ences, as they generate the greatest volume of information on a subject. Even though their impact is smaller, it remains an acceptable option. Regarding the language and considering the findings, our recommendation is that all the papers should be published in English, not diminishing the importance of the language of future researchers.

\section{DISCUSSION}

Bibliometric mapping of scientific literature is used to delve deep into fields and areas of knowledge, and to help establish the underlying structure around it (Sinkovics, 2016).

As seen in this study, it was in 2016 when the number of scientific publications related to active methodologies started to rise, multiplying in subsequent years. This is related to publications in which the use and development of ICTs in education during those years seems to encourage students to develop more positive skills for learning through technology (Todeschini \& Baccini, 2016). Additionally, compliance with three classic laws of bibliometric 
analysis was verified: Bradford's Law (1985), Price’s Law (1986) and Lotka's Law (1926), all theorized more than 30 years ago, but still capable of explaining current scientific evolution.

From the results, it can be stated that high production of scientific papers does not guarantee high impact, as other investigations have revealed (Ávila Toscano, Pérez, Guajardo, \& Marenco-Escuderos, 2018). Impact depends more on visibility and citations in the short term, than on other factors (Abramo, D'Angelo, \& Felici, 2019). Thus, this study also shows that for the topic of active methodologies, journals are the most effective medium to publicize completed studies. This fact is due to the low capacity of WOS to correctly index the citations of conferences (Baneyx, 2008), as well as the lesser interest of researchers in aiming their efforts towards this sort of publication (Bakkum \& Chapman, 2017).

Considering the authors' genders, women were largely found to be major producers compared to men. This fact is relevant, because in most bibliometric studies women are usually a minority, being relegated to the last positions (González-Álvarez \& Cervera-Crespo, 2017) and, as happens in this case, they are not counted within documents that have a high number of citations (Beaudry \& Lariviere, 2016).

The results around language are not new; English hegemony is simple to explain. Despite the fact that most publications are generated in countries such as Spain or Brazil, the potential for dissemination in English is much greater, being considered the language for world scientific communication (Martín, 2016). Furthermore, WOS has set its own penalties when the documents are published in a language other than English (Hamel, 2007).

Finally, the most relevant topics distinguished concur with specific studies showing the scientific potential and the large number of documents in recent years on flipped classroom (Yang, Sun, \& Liu, 2017) and project-based learning (Azer, 2017; Reis, Barbalho, \& Zanette, 2017).

\section{CONCLUSIONS}

This paper evaluated global research trends in publications on active methodologies in education from 2009 to 2019 . The subject was analyzed through exhaustive research on the last 10 years in this field, finding that publications on active methodologies increased exponentially between 2013-2018.

Therefore, a growing interest in research related to active methodologies was detected, consistent with the need for transformation of the current educational processes. Based on the analysis of key words, the terms flipped classroom (and inverted class) and project-based learning stand out as preferred research topics in terms of future projections.

In contributions to international educational conferences (indexed in WOS), researchers and teachers can find the most assorted material, experience accumulated by teachers and research or other relevant information for their studies.

Classical authors, those related to the most important theories in the educational field, are cited in most studies, indicating the importance of classical theories as the basis for the development of new methodologies. 
Spain is the country that carries out the majority of work with other countries, most of which are also Spanish-speaking, although the main core of their research is with other Spanish universities. This is relevant as, despite the fact that Spanish universities retain the most collaboration networks and are one of the largest generators of this kind of content, the first output language is always English.

Finally, among the limitations found throughout the development of this study, we can highlight the problems with selection of information and administering the filters in the last phase. Although the quantity of documents handled was moderate (587), the automation of the filters (especially filtering by keywords) should be taken into account for subsequent studies. Regarding future lines of research, it is proposed to replicate the study in other databases such as Scopus, Google Scholar and to carry out in-depth analysis of the different social networks formed around the subject, which will offer the scientific community valuable information on active methodologies.

\section{REFERENCES}

Abramo, G., D’Angelo, C. A., \& Felici, G. (2019). Predicting publication long-term impact through a combination of early citations and journal impact factor. Journal of Informetrics, 13(1), 32-49. https://doi.org/10.1016/j.joi.2018.11.003

Arenas-Loera, E. P. (2017). Estrategias de estilos de aprendizaje de estudiantes: Proceso de validación. Alteridad, 12(2), 224-237. https://doi.org/10.17163/alt.v12n2.2017.08

Arguimbau-Vivó, L., Fuentes-Pujol, E., \& Gallifa-Calatayud, M. (2000). Una década de investigación documental sobre cienciometría en España: Análisis de los artículos de la base de datos ISOC. Revista Española de Documentación Científica, 36(2), 1-9. https://doi.org/10.3989/redc.2013 .2 .907

Arthur, J. (2016). Convergence on Policy Goals: Character Education in East Asia and England. Journal of International and Comparative Education, 5(2), 59-72. https://doi.org/10.14425/ jice.2016.5.2.59

Ávila Toscano, J. H., Pérez, I. R., Guajardo, E. S., \& Marenco-Escuderos, A. (2018). Influencia de la producción de nuevo conocimiento y tesis de postgrado en la categorización de los grupos de investigación en Ciencias Sociales: árbol de decisiones aplicado al modelo científico colombiano. Revista española de Documentación Científica, 41(4), 218-218. https://doi.org/ 10.3989/redc.2018.4.1547

Azer, S. (2017). Top-Cited Articles in Problem-Based Learning: A Bibliometric Analysis and Quality of Evidence Assessment. Journal of Dental Education, 81(4), 458-478. https://doi.org/ 10.21815/JDE.016.011

Bai, S., Hew, K. F., \& Huang, B. (2020). Does gamification improve student learning outcome? Evidence from a meta-analysis and synthesis of qualitative data in educational contexts. Educational Research Review, 30, 100322-100322. https://doi.org/10.1016/j.edurev.2020.100322

Bakkum, B. W., \& Chapman, C. (2017). Barriers to peer-reviewed journal article publication of abstracts presented at the 2006-2008 Association of Chiropractic Colleges Educational Conference and Research Agenda Conference Meetings. Journal of Chiropractic Education, 31(1), 20-26. https://doi.org/10.7899/jce-14-21

Baneyx, A. (2008). "Publish or Perish" as citation metrics used to analyze scientific output in the humanities: International case studies in economics, geography, social sciences, philosophy, and history. Archivum Immunologiae et Therapiae Experimentalis, 56(6), 363-371. https:// 


\section{doi.org/10.1007/s00005-008-0043-0}

Beaudry, C., \& Lariviere, V. (2016). Which gender-gap? Factors affecting researchers' scientific impact in science and medicine. Research Policy, 45(9), 1790-1817. https://doi.org/10.1016/ j.respol.2016.05.009

Bernal-González, M., Martínez-Dueñas, C., \& S, M. (2017). Metodologías activas para la enseñanza y el aprendizaje. Revista Panamericana de Pedagogía, 1(25), 271-275.

Biggs, J. B. (2015). Calidad del aprendizaje universitario. Narcea.

Bradford, S. C. (1985). Sources of information on specific subjects. Journal of Information Science, 10(4), 176-180. https://doi.org/10.1177/016555158501000407

Brewer, R., Anthony, L., Brown, Q., Irwin, G., Nias, J., \& Tate, B. (2013). Using gamification to motivate children to complete empirical studies in lab environments. Proceedings of the 12th International Conference on Interaction Design and Children - IDC '13 (pp. 388-391). https:// doi.org/10.1145/2485760.2485816

Burganova, R., Abdullina, S., \& Tuyakova, A. (2018). Improving the Quality of Education Through Student-Centered Education. Series of Social and Human Sciences, 6, 102-104.

Cechetti, N. P., Bellei, E. A., Biduski, D., Rodriguez, J. P. M., Roman, M. K., \& Marchi, A. C. B. D. (2019). Developing and implementing a gamification method to improve user engagement: A case study with an $\mathrm{m}$-Health application for hypertension monitoring. Telematics and Informatics, 41, 126-138. https://doi.org/10.1016/j.tele.2019.04.007

Coll, C. (1997). Aprendizaje escolar y construcción del conocimiento. Paidós.

Contreras-Gastelum, Y. I., \& Lozano-Rodriguez, A. (2012). Aprendizaje auto-regulado como competencia para el aprovechamiento de los estilos de aprendizaje en alumnos de educación superior. Revista de Estilos de Aprendizaje, 5(10), 114-147.

Davies, I., \& Chong, E. K. M. (2016). Current challenges for citizenship education in England. Asian Education and Development Studies, 5(1), 20-36. https://doi.org/10.1108/aeds-05-2015-0015

Dios, J. G. D., Muñoz, M. G., Alonso-Arroyo, A., \& Benavent, R. (2013). Fundamentos para la realización de la revisión bibliográfica en investigación sociosanitaria. Acta Pediátrica Española, 69(3), 131-136.

Fernandez-March, A. (2006). Metodologías activas para la formación de competencias. Educatio Siglo XXI, 24(1), 35-56.

Flores, C., Aguilera, R., Saldivia, A. M., Gutiérrez, V., Pérez, V., \& Torres, L. M. (2018). Análisis bibliométrico de la Revista de la Sociedad Española del Dolor: 2007-2016. , 25. https://doi.org/ 10.20986/resed.2018.3627/2017

Gómez-López, R. (2002). Análisis de los métodos didácticos en la enseñanza. PUBLICACIONES, 32(1), 261-334. https://doi.org/10.30827/publicaciones.v32i0.2334

González-Álvarez, J., \& Cervera-Crespo, T. (2017). Research production in high-impact journals of contemporary neuroscience: A gender analysis. Journal of Informetrics, 11(1), 232-243. https://doi.org/10.1016/j.joi.2016.12.007

Hamel, R. E. (2007). The dominance of English in the international scientific periodical literature and the future of language use in science. AILA Review, 20(1), 53-71. https://doi.org/10.1075/ aila.20.06ham

Hidalgo, N., \& Perines, H. (2018). Give Voice to the Participants: Student Participation in the Teaching-Learning Process. Revista Educación, 42(2), 438-464. https://doi.org/10.15517/ revedu.v42i2.27567

Jiménez-Noblejas, C., \& Rodríguez, A. P. (2014). Recuperación y visualización de información en Web of Science y Scopus: una aproximación práctica. Investigación Bibliotecológica: Archivonomía, Bibliotecología e Información, 28(64), 15-31. https://doi.org/10.1016/ S0187-358X(14)70907-4 
Lotka, A. J. (1926). The frequency distribution of scientific productivity. Journal of the Washington Academy of Sciences, 16(12), 317-323.

Marchesi, A., Coll, C., \& Palacios, J. (2018). Desarrollo psicológico y educación (3rd ed.). Alianza Editorial.

Martín, M. L. S. (2016). La lengua inglesa y su importancia en la investigación en enfermería. Ciencia y Enfermería, 22(1), 7-9. https://doi.org/10.4067/s0717-95532016000100001

Masero-Moreno, I. (2016). Una propuesta didáctica basada en las TIC y las metodologías activas centradas en el alumno para el desarrollo de competencias. Anales de ASEPUMA, 24(1), 1-22.

Méndez-García, R. M., \& Trillo-Alonso, J. F. (2010). El papel de la información universitaria en el proceso de formación de actitudes de los estudiantes hacia la universidad. Revista de Educación, 353, 299-300.

Miguel, S., Moya-Anegon, F., \& Herrero-Solana, V. (2007). El análisis de co-citas como método de investigación en Bibliotecología y Ciencia de la Información. Investigación bibliotecológica, 21(43), 139-155. https://doi.org/10.22201/iibi.0187358xp.2007.43.4129

Moed, H., \& Glänzel, W. (2005). Kluwer Academic Publishers.

Moher, D., Liberati, A., Tetzlaff, J., \& Altman, D. G. (2009). Preferred Reporting Items for Systematic Reviews and Meta-Analyses: The PRISMA Statement. PLoS Medicine, 6(7), e1000097e1000097. https://doi.org/10.1371/journal.pmed.1000097

Moher, D., Shamseer, L., Clarke, M., Ghersi, D., Liberati, A., Petticrew, M., ... Stewart, L. A. (2015). Preferred reporting items for systematic review and meta-analysis protocols (PRISMA-P) 2015 statement. Systematic Reviews, 4(1), 1-6. https://doi.org/10.1186/2046-4053-4-1

Morales, R. E., \& Pereida, M. A. (2017). Inclusión de estilos de aprendizaje como estrategia didáctica aplicada en un AVA. Campus Virtuales, 6(1), 67-75.

Nielsen-Rodriguez, A., Romance-Garcia, A. R., \& Minguet, J. L. (2020). Los ambientes de aprendizaje como metodología activa promotora de la actividad física en Educación Infantil. Un estudio de caso. Retos, 1(37), 498-504.

Paños-Castro, J. (2017). Educación emprendedora y metodologías activas para su fomento. Revista Electrónica Interuniversitaria de Formación del Profesorado, 20(3), 33-33. https://doi.org/10 .6018/reifop.20.3.272221

Parra-González, M. E., Belmonte, J. L., Segura-Robles, A., \& Cabrera, A. F. (2020). Active and Emerging Methodologies for Ubiquitous Education: Potentials of Flipped Learning and Gamification. Sustainability, 12(2), 602-602. https://doi.org/10.3390/su12020602

Parra-González, M. E., \& Segura-Robles, A. (2019a). Análisis de las experiencias gamificadas de docentes y alumnos de Educación Secundaria. Revista Espacios, 40(23), 15-25.

Parra-González, M. E., \& Segura-Robles, A. (2019b). Producción científica sobre gamificación en educación: Un análisis cienciométrico. Revista de Educación, 5(386), 113-131.

Parra-González, M. E., Segura-Robles, A., \& Gómez-Barajas, E. R. (2020). Assessing Gamified Experiences in Physical Education Teachers and Students. IJERI: International Journal of Educational Research and Innovation, 1(13), 166-176.

Pérez-López, I., \& García, E. R. (2017). Formar docentes, formar personas: análisis de los aprendizajes logrados por estudiantes universitarios desde una experiencia de gamificación. Signo y Pensamiento, 36, 112-112. https://doi.org/10.11144/javeriana.syp36-70.fdfp

Price, D. J., \& De, S. (1986). Little science, big science and beyond. Columbia University Press.

Reis, A. C. B., Barbalho, S. C. M., \& Zanette, A. C. D. (2017). A bibliometric and classification study of Project-based Learning in Engineering Education. Production, 27, 1-16. https://doi.org/ 10.1590/0103-6513.225816

Reyes-Gonzalez, L., Gonzalez-Brambila, C. N., \& Veloso, F. (2016). Using co-authorship and citation analysis to identify research groups: a new way to assess performance. Scientometrics, 108(3), 


\section{1-1191. https://doi.org/10.1007/s11192-016-2029-8}

Romero, J. F. G., Pérez, C. V. V., \& Pérez, R. A. V. (2020). La formación de profesionales competentes e innovadores mediante el uso de metodologías activas. Revista Universidad y Sociedad, 12, 343-349.

Rousseau, R., Egghe, L., \& Guns, R. (2018). Becoming metric-wise: A bibliometric guide for researchers. Chandos.

Silva-Quiroz, J., \& Maturana-Castillo, D. (2017). Una propuesta de modelo para introducir metodologías activas en educación superior. Innovación educativa, 17, 117-131.

Sinkovics, N. (2016). Enhancing the foundations for theorising through bibliometric mapping. International Marketing Review, 33(3), 327-350. https://doi.org/10.1108/imr-10-2014-0341

Soto, N. C., Navas-Parejo, M. R., \& Guerrero, A. J. M. (2019). Realidad virtual y motivación en el contexto educativo: Estudio bibliométrico de los últimos veinte años de Scopus. Alteridad, 15(1), 47-60. https://doi.org/10.17163/alt.v15n1.2020.04

Todeschini, R., \& Baccini, A. (2016). Handbook of bibliometric indicators: Quantitative tools for studying and evaluating research. (1st ed.). Wiley. https://doi.org/10.1002/9783527681969

Xi, N., \& Hamari, J. (2020). Does gamification affect brand engagement and equity? A study in online brand communities. Journal of Business Research, 109, 449-460. https://doi.org/10.1016/ j.jbusres.2019.11.058

Yang, L., Sun, T., \& Liu, Y. (2017). A Bibliometric Investigation of Flipped Classroom Research during 2000-2015. International Journal Of Emerging Technologies In Learning (Ijet), 12(06), 178-178. https://doi.org/10.3991/ijet.v12i06.7095 